\title{
Mood disorder induced by prednisolone - an easily overlooked complication
}

Zaburzenia afektywne wywołane przez prednizolon - problem medyczny łatwy do przeoczenia

\author{
Nicholas Pang ${ }^{1}$ ABCDEF, https://orcid.org/0000-0003-1659-6374, \\ Ruziana Masiran² DEF, https://orcid.org/0000-0002-9987-4255
}

${ }^{1}$ Faculty of Medicine and Health Sciences, University Malaysia Sabah, Malaysia

${ }^{2}$ Department of Psychiatry, Faculty of Medicine and Health Sciences, University Putra

Malaysia, Selangor, Malaysia

\begin{abstract}
Objective: The use of corticosteroids might be associated with the sequelae of psychiatric comorbidity - manic and depressive symptoms, psychosis, and cognitive impairment.

Case report: We report a case of the 35 years old man who presented seven months period of irritability, occasional low mood, and sleep disturbances without the concurrent hallucinations or delusions. The patient had a history of nephrotic syndrome and for this reason, required prednisolone. The corticosteroid induced irritability that has appeared three months after the treatment has started. The psychiatric examination showed neither the psychomotor retardation, manic or depressed mood, nor hallucinations and delusions. However, the level of irritability was undoubtedly increased.

Conclusions: Corticosteroids are drugs commonly used in many systemic diseases. During a psychiatric examination, a careful evaluation is necessary to distinguish the side effects of corticosteroids from the primary psychiatric disorders.
\end{abstract}

Keywords: corticosteroid, mood disorder, side effect

\section{Streszczenie}

Wstęp: Stosowanie glikokortykosteroidów może być związane z współwystępowaniem objawów psychopatologicznych, w tym objawów maniakalnych, depresyjnych, psychotycznych, czy z osłabieniem funkcji poznawczych.

Opis przypadku: Przedstawiono przypadek 35 letniego mężczyzny, u którego przez okres siedmiu miesięcy występowało rozdrażnienie, okresowo obniżony nastrój oraz zaburzenia snu. Nie obserwowano występowania halucynacji ani urojeń.

Mężczyzna w przeszłości cierpiał na zespół nerczycowy, co wiązało się z koniecznością leczenia prednizolonem. Kortykosteroid wywołał drażliwość, która ujawniła się trzy miesiące po rozpoczęciu leczenia. Podczas badania psychiatrycznego pacjent nie wykazywał objawów związanych ze spowolnieniem psychoruchowym, stanami maniakalnymi, depresyjnymi, halucynacjami, omamom przeczył, jego zachowanie nie skazywało na ich przeżywanie. Pacjent zgłaszał występowanie nasilonego rozdrażnienia, które utrzymywało się od dłuższego czasu.

Wnioski: Glikokortykosteroidy to leki powszechnie stosowane w wielu chorobach ogólnoustrojowych. Podczas badania psychiatrycznego konieczne jest ostrożne różnicowanie skutków ubocznych działania glikokortykosteroidów od pierwotnych zaburzeń psychicznych.

Słowa kluczowe: glikokortykosteroidy, zaburzenia afektywne, objawy uboczne

\section{Introduction}

The use of steroids is associated with the consequences of mental illnesses, including manic and depressive symptoms, psychosis, and cognitive impairment $[1,2,3]$. Careful evaluation should be made to distinguish their side effects from a primary psychiatric disorder.

\section{Case presentation}

A 35-year-old man with the nephrotic syndrome had psychiatric symptoms for seven months. The predominant trait was irritability, which was associated with sporadic physical aggression towards other people. The patient also presented decreased concentration and interrupted sleep. 
He also had occasional low mood and suicidal thoughts. All of these symptoms appeared three months after starting $10 \mathrm{mg}$ of oral prednisolone per day. The symptoms were more severe as the prednisolone dose was increased from $20 \mathrm{mg}$ to $30 \mathrm{mg}$ per day. All symptoms disappeared within one week after reducing the prednisolone dose from $30 \mathrm{mg}$ to $10 \mathrm{mg}$ and resolved completely one week after stopping prednisolone. Apart from irritation during treatment with prednisolone, there were no obvious cognitive impairment, anhedonia, anergy, manic or psychotic symptoms. There were no signs of obstructive sleep apnea, e.g., snoring, daytime sleepiness, or headache. The patient had no symptoms suggesting any cognitive impairment. His Daily Living Activities (ADL) and the functional review showed an independent person without impairing any aspect of ADL or instrumental ADL despite his chronic disease.

Due to the persistent irritability, the patient consulted a psychiatrist. Idiopathic nephrotic syndrome was diagnosed one year before the consultation. The patient did not suffer from any diseases of the central nervous system, e.g. systemic lupus erythematosus, which could be a triggering factor for nephrotic syndrome. The patient had no family history of neurological or psychiatric diseases, was well-functioning, received eleven years of formal education, and had a job. He smoked half a pack of cigarettes a day, drank alcohol only occasionally, but used marijuana in small amounts to ease the emotions. The family and acquaintances described the patient as a friendly man who coped well with everyday problems.

A psychiatric examination revealed a young, slightly obese man maintaining satisfactory personal hygiene, eye contact, and logical verbal contact. The patient spoke at a normal pace, pitch, and volume and was consistent and relevant. The mood could be described as euthymic. The patient showed no hallucinations, delusions, or suicidal thoughts, was properly oriented autopsychically and allopsychically, attention and concentration were not impaired. A physical examination including a complete neurological examination showed no obvious abnormalities.

The full blood count, thyroid, and liver function tests showed no abnormalities. Kidney function tests showed a chronic picture of nephrotic syndrome. Glucose, cholesterol, and triglycerides were not disturbed. The blood sugar level was in the range of 5.4-8.6 mmol / $\mathrm{l}$. Ambulatory blood pressure values were within the normal range.

According to the DSM 5 criteria (APA, 2013), the diagnosis for the patient in the presented case should be "Bipolar and related disorder due to another disease" (F06.3 according to ICD-10). The symptoms presented by the patient were consistent with the first DSM 5 criterion, there was a clear and persistent mood disorder that dominated the clinical picture. It was manifested both by the irritability and depression. Moreover, according to the second DSM 5 criterion, medical history, and physical examination clearly indicated a direct pathophysiological relationship between the use of corticosteroid and mood symptoms. Furthermore, the symptoms did not persist in a manner that would indicate a primary psychiatric disorder, namely, no mood disturbances were present for more than one month after discontinuation of prednisolone treatment. When conducting a differential diagnosis, bipolar disorder had to be taken into account in this case, however, the time relationship between symptoms and the causative agent suggested that the proposed diagnosis was more likely. The patient also met criteria 3 and 4 of DSM 5.

It was decided to start treatment with alprazolam, a short-acting benzodiazepine at a low dose of $0.25 \mathrm{mg}$, which the patient could use when needed. However, the symptoms persisted, and the patient received multiple antidepressants and antipsychotics, including escitalopram up to $20 \mathrm{mg}$ for two months, which was switched to mirtazapine $45 \mathrm{mg}$ for three months. Later, mirtazapine was changed to aripiprazole up to $20 \mathrm{mg}$ for two months. Still, none of these drugs resulted in any apparent improvement in symptoms.

After starting medication, the mood was described as euthymic, but the patient continued to experience occasional bouts of irritability. The only time when the mood was balanced over a long period was when steroids were withdrawn, however, a team of nephrologists recommended oral prednisolone at a dose of $10 \mathrm{mg}$ per day because proteinuria persisted. When steroid treatment was resumed, irritability increased and the patient unsuccessfully attempted suicide by drug overdose.

As a result, the patient started psychotherapy. Taking the failure of many prior pharmacotherapies into consideration, the patient was given only the necessary amounts of $0.25 \mathrm{mg}$ alprazolam after restarting steroid therapy. Further treatment was possible on an outpatient basis. Psychotherapeutic activities contributed to the reduction of pharmacological treatment. After some time, cyclosporine was introduced, which did not induce mood changes and decreased the need for benzodiazepine use.

\section{Discussion}

Corticosteroids can contribute to many ailments; this also applies to psychiatric disorders. Clinical vigilance is important as many of the chronic conditions treatable with corticosteroids, which can cause side effects, can also be independently related to mood disorders. Mood disorders associated with glucocorticoid side effects are uncommon but may occur [1]. Most studies suggest 
manic symptoms rather than depressive symptoms as the main presenting ailment [2]. It also appears to be a dosedependent response [3]. Moreover, it is sometimes stated that cognitive disorders are consistent with the picture of dementia [4], and in the described patients there are disturbances in attention, concentration, and verbal memory problems [5].

It has been shown that the most effective treatment of psychiatric symptoms is achieved by reducing the dose of corticosteroids [6]. The evidence that lithium can be used appears to be only anecdotal [7]. In fact, case reports have shown that tricyclic antidepressants can paradoxically worsen symptoms [8]. On the other hand, there seems to be no simple solution to cognitive problems other than with corticosteroid withdrawal. Hence, there appears to be a need to alert patients to the potential psychiatric side effects of corticosteroid treatment in any disease. A persistent search for alternative non-steroidal therapies for many diseases is another way to avoid the problem. The examples include methotrexate for rheumatoid arthritis and leukotrienes for asthma.

Given such limited and insufficient evidence for the treatment of any corticosteroid-induced mental disorder, a reduction in steroid use as the basis for the treatment of mood symptoms would be advisable. Lithium is the only drug tested in a controlled treatment setting for steroid-induced psychiatric symptoms and should be started at a dose of 600-900 mg/day [9]. In cases where antidepressants are used, there is little evidence to suggest that an selective serotonin reuptake inhibitor (SSRI) should be given priority over a tricyclic antidepressant [10]. Besides, there is little data on the possibility of using olanzapine (an atypical antipsychotic drug) in the treatment of psychiatric disorders caused by steroids [11]. All these treatment options need to be balanced against the risk of starting a second drug and the side effects that come with it.

\section{Conclusion}

Corticosteroids are ubiquitous drugs used in many systemic diseases. However, one of the most unpleasant side effects is psychiatric symptoms. Therefore, caution should be exercised in prescribing corticosteroids, and alternatives should always be sought whenever possible to avoid side effects and the resulting dissatisfaction in patients. Psychiatric side effects of corticosteroids should be monitored and treated.

\section{Conflict of interest}

The authors have declared no conflict of interest.

\section{References}

1. Rosenblat JD, Cha DS, Mansur RB, McIntyre RS. Inflamed moods: a review of the interactions between inflammation and mood disorders. Progress in Neuro-Psychopharmacology and Biological Psychiatry. 2014;53:23-34.

2. Wada K, Yamada N, Suzuki H, Kuroda S. Recurrent cases of corticosteroid-induced mood disorder: clinical characteristics and treatment. The Journal of clinical psychiatry. 2000;61(4):261-7.

3. Ciriaco M, Ventrice P, Russo G, Scicchitano M, Mazzitello G, Scicchitano F, Russo E. Corticosteroid-related central nervous system side effects. Journal of pharmacology \& pharmacotherapeutics. 2013;4:S94.

4. Judd LL, Schettler PJ, Brown ES, Wolkowitz OM, Sternberg EM, Bender BG, Bulloch K, Cidlowski JA, Ronald de Kloet E, Fardet L, Joëls M. Adverse consequences of glucocorticoid medication: psychological, cognitive, and behavioral effects. American Journal of Psychiatry. 2014;171(10):1045-51.

5. Bhangle SD, Kramer N, Rosenstein ED. Corticosteroidinduced neuropsychiatric disorders: review and contrast with neuropsychiatric lupus. Rheumatology international. 2013;33(8):1923-32.

6. Lotan I, Fireman L, Benninger F, Weizman A, Steiner I. Psychiatricsideeffectsofacute high-dose corticosteroidtherapy in neurologicalconditions. International clinicalpsychopharmacology. 2016;31(4):224-31.

7. Campbell R, Tycon L, Pruskowski J. Corticosteroid-Induced Psychiatric Symptoms\# 323. Journal of palliative medicine. 2017;20(3):298-9.

8. Hall RC, Popkin MK, Stickney SK, Gardner ER. Presentation of the steroid psychoses. The Journal of nervous and mental disease. 1979;167(4):229-36.

9. Falk WE, Mahnke MW, Poskanzer DC. Lithium Prophylaxis of Corticotropin-Induced Psychosis. JAMA. 1979;241(10):1011-2.

10. Wyszynski AA, Wyszynski B. Treatment of depression with fluoxetine in corticosteroid-dependent central nervous system Sjögren's syndrome. Psychosomatics. 1993;34(2):173-7.

11. Brown ES, Khan DA, Suppes T. Treatment of corticosteroidinduced mood changes with olanzapine. American Journal of Psychiatry. 1999;156(6):968.

\section{Corresponding author}

Dr Nicholas Pang, Department of Psychiatry, Faculty of Medicine and Health Sciences, University Malaysia Sabah, 88400 Jalan UMS, Kota Kinabalu, Malaysia email: nicholas86@gmail.com

Otrzymano; 18.07 .2019

Zrecenzowano; 07.08.2019

Przyjęto to druku: 27.10.2020 